\title{
POLYMYXINS - ANTIBACTERIAL ACTIVITY, RESISTANCE MECHANISMS AND EPIDEMIOLOGY OF PLASMID MEDIATED RESISTANCE
}

\section{POLIMIKSINI - ANTIBAKTERIJSKA AKTIVNOST, MEHANIZMI REZISTENCIJE I EPIDEMIOLOGIJA REZISTENCIJE POSREDOVANE PLAZMIDOM}

\author{
Snežana Brkić ${ }^{1}$, Dragana Božić ${ }^{2}$, Ivana Ćirković ${ }^{3}$
}

\begin{abstract}
${ }^{1}$ Institute for Laboratory Diagnostics “Konzilijum”, Belgrade, Serbia
${ }^{2}$ University of Belgrade, Faculty of Pharmacy, Department of Microbiology and Immunology, Belgrade, Serbia

${ }^{3}$ University of Belgrade, Faculty of Medicine, Institute of Microbiology and Immunology, Belgrade, Serbia
\end{abstract}

Correspondence: brkic.snezana@gmail.com

\section{Abstract}

The occurrence and spreading of multi-resistant, as well as pan-resistant bacterial isolates, presents a global problem of modern medicine. Narrowed therapeutic options actualized the use of "old" antibiotics such as polymyxins. The use of polymyxins in human medicine has been reduced since the 1960s due to the discovery of safer antibiotics. Modern researches provided a better understanding of their pharmacokinetics and pharmacodynamics, as well as dosing regimens with minimum side effects. However, the increased usage in therapy consequently led to the occurrence of resistance to these "last-line" antibiotics. Most of polymyxin resistant bacterial isolates carried chromosomally mediated resistance, but the discovery of the plasmid $m c r-1$ gene in 2015 in China changed the paradigm of the origin and spreading of

Keywords: polymyxins, resistance mechanisms, mor-1 gene, plasmid polymyxin resistance. Animals are the main reservoirs of bacteria carrying plasmid with the mcr-1 gene, because of widespread polymyxins application in veterinary medicine and in food industry, as well. Many studies confirmed the transfer of polymyxins resistance genes from animal bacterial isolates to human isolates, as well as between different bacterial species in vivo or in vitro. These findings indicated the need for more detailed epidemiological research and surveillance, as the European Centre for Disease Prevention and Control recommended.

Brkić S. et al. MedPodml 2019, 70(3):1-6 (c)

The authors declare no conflicts of interest. doi:10.5937/mp70-19934

Editorial board: podmladak.med.bg@gmail.com e-ISSN: 2466-5525 
Brkić S. et al. Polymyxins - Antibacterial Activity, Resistance Mechanisms and Epidemiology of Plasmid Mediated Resistance. MedPodml

\section{Sažetak}

Pojava i širenje multirezistentnih, ali i panrezistentnih sojeva bakterija predstavlja problem globalnih razmera u savremenoj medicini. Sužen terapijski izbor aktuelizovao je upotrebu "starih" antibiotika, kao što su polimiksini. Korišćenje polimiksina u humanoj medicini smanjeno je šezdesetih godina XX veka zbog otkrića bezbednijih antibiotika. Savremena istraživanja su omogućila bolje razumevanje njihove farmakokinetike i farmakodinamike, kao i doziranje koje minimizira pojavu neželjenih efekata. Povećana upotreba polimiksina u terapiji dovela je, međutim, do pojave rezistencije na ove antibiotike "poslednje linije". Najveći broj izolata bakterija rezistentnih na polimiksine ima hromozomski posredovanu rezistenciju. Otkriće plazmidskog gena mor-1 2015. godine u Kini promenilo je paradigmu o poreklu i širenju rezistencije na polimiksine. Glavni rezervoar bakterija nosilaca plazmidskog gena su životinje zbog izuzetno velike primene polimiksina u veterinarskoj medicini, ali i u proizvodnji hrane. U brojnim studijama

Ključne reči:

polimiksini, mehanizmi rezistencije, mor-1 gen, plazmid potvrđen je prenos gena rezistencije na polimiksine sa animalnih bakterijskih izolata na izolate humanog porekla, kao i prenos između različitih bakterijskih vrsta in vivo ili in vitro. Ova saznanja su nametnula potrebu za detaljnim epidemiološkim istraživanjima i nadzorom nad ovim tipom rezistencije, što je i preporuka Evropskog centra za prevenciju i kontrolu bolesti.

The occurrence and spreading of multi-resistant Gram-negative bacteria, which are resistant to at least one agent in three or more different categories of antibacterial drugs (1), compromised the treatment of even the simplest infections. The development of new antibiotics is necessary, but their introduction into clinical practice is long-term and expensive. One strategy for overcoming this problem lies in the usage of the antibiotics, such as polymyxins. Polymyxins were discovered 70 years ago. Pharmacokinetics (PK) and pharmacodynamics (PD) data were poor, and nephrotoxicity and neurotoxicity, as well as the discovery of safer antibiotics, limited their usage (2). Recent studies enabled better understanding of PK/PD parameters and the optimization of a dosage regimen, resulting in the actualization of polymyxins in therapeutic protocols $(3,4)$. Unfortunately, the increased usage led to the resistance to these "last-line" antibiotics.

\section{The structure and mechanism of action of polymyxins}

Polymyxins are cyclic, hydrophilic, cationic peptides, very similar to antimicrobial peptides of eukaryotic cells (e.g. defensins). They are natural products of Paenibacillus polymyxa. Among five classes of polymyxins, polymyxin $\mathrm{B}$ and polymyxin $\mathrm{E}$ (colistin) are the most important in clinical practice. They differ in one amino acid in the peptide ring - phenylalanine in polymyxin $\mathrm{B}$ and leucin in polymyxin $\mathrm{E}$. This has a great impact on PD: polymyxin B is applied as active drug, while colistin as inactive, less toxic precursor, colistimethate sodium. Colistimethate sodium converts in aqueous environment, such as body fluids, to its active form. The other form of colistin is colistin sulphate, administered orally for digestive tract decolonization or for topical treatment of skin infections (5).
The cell membrane of Gram-negative bacteria is the target of the action of these antibiotics. Positively charged polymyxins react with phosphate groups of lipid A of negatively charged lipopolysaccharide (LPS), replacing $\mathrm{Ca}^{2+}$ and $\mathrm{Mg}^{2+}$ ions. This results in the destabilization of LPS, loss of cell wall integrity, and cell death. Polymyxins, also, neutralize endotoxin effects by binding to LPS released from the bacterial wall after cell death (5).

Polymyxins are bactericidal antibiotics and the antibacterial effect depends on the serum concentration level. The best PK-PD parameter predicting their activity is the area under the concentration-time curve for free drug (fAUC) to minimum inhibitory concentration (MIC), which indicates the importance of maintaining the concentration of the drug in serum over the time. According to the recommendations of the European Medicines Agency (EMA) from 2014, the therapeutic concentration of colistin is $2 \mu \mathrm{g} / \mathrm{ml}$. Achieving the steady state of the colistin concentration in plasma depends on the proper renal function, because colistimethate sodium is converted into the active drug in kidneys. When renal function decreases, more prodrug is converted into the active form. In healthy individuals only $20-30 \%$ of the precursor is converted, but in patients with creatinine clearance below $50 \mathrm{ml} / \mathrm{min}$, the converted portion could be as high as $60-70 \%$, thus reduction in doses are recommended $(6,7)$.

In accordance with the above, achieving the therapeutic concentration of colistin may be difficult in healthy people, but dose increasing could lead to a higher incidence of side effects (e.g. nephrotoxicity and neurotoxicity) $(7,9)$. This can be partially avoided with synergistic combinations of colistin and other antibacterial drugs (hydrophilic antibiotics like carbapenems, rifampicin, glycopeptides and tetracyclines) $(3,6,7)$. Several patients' characteristics, such as renal function, age, and body weight require practically individual dosing in order to achieve the therapeutic concentration and effectiveness of 
Brkić S. et al. Polymyxins - Antibacterial Activity, Resistance Mechanisms and Epidemiology of Plasmid Mediated Resistance. MedPodml

the treatment. Many studies showed that suboptimal doses led to drug resistance, with minimal post-antibiotic effect, especially in Klebsiella pneumoniae, Acinetobacter baumannii, and Pseudomonas aeruginosa. Therefore, maintaining optimal polymyxins concentration level in patients' serum is important both in therapy and in order to avoid the development of resistant bacterial clones $(2,4,6-8)$.

The polymyxins activity spectrum includes Gram-negative bacteria, like Enterobacteriaceae such as Escherichia coli, Klebsiella spp., Enterobacter spp., Salmonella spp., Shigella spp., Citrobacter spp. and non-fermentative Gram-negative bacteria such as Pseudomonas aeruginosa, Acinetobacter spp., and Stenotrophomonas maltophilia. However, a significant number of species shows intrinsic resistance to these antibiotics, like Proteus spp., Morganella morganii, Providencia spp., Serratia marcescens, Campylobacter spp., Moraxella spp., Neisseria spp., as well as all Gram-positive and anaerobic bacteria (6).

\section{Mechanisms of resistance to polymyxins}

The most common mechanism of resistance to polymyxins in Enterobacteriaceae is chromosomally encoded changes of the binding site of these antibiotics, the lipid $\mathrm{A}$ in LPS. The addition of phosphoethanolamine (pEtN) or 4-amino-4-deoxy-L-arabinose (L-Ara-4N) to the lipid A on the membrane surface disables polymyxins activity through the reduction of negative charge. Genes coding enzymes involved in these modifications are located on pmrHFIJFKLM and pmrCAB operons. Their activity is regulated by $p m r A B$, phoPQ, and $m g r B$ genes, which expression depends on environmental conditions (phagocytosis, low $\mathrm{pH}, \mathrm{Fe}^{2+}, \mathrm{Mg}^{2+}$ and other ions concentration) (6,10-12).

PmrAB two-component system is activated naturally during bacterial phagocytosis by macrophages and enables the survival of the bacterial cell. PmrB protein, as tyrosine kinase, phosphorylates and activates PmrA protein, which increases the transcription of pmrHFIJFKLM and $p m r C A B$ genes responsible for lipid A modifications. The second two-component system, $P h o P Q$, increases the expression of genes involved in the magnesium transport, lipid A modification and bacterial survival in low $\mathrm{pH}$ conditions. Specific mutations in $P m r A B$ and $P h o P Q$ regions lead to their constitutive expression and chromosomally encoded resistance to polymyxins. The $\operatorname{mgrB}$ gene is also involved in negative regulation of $P h o P Q$ system, and its inactivation (due to missense or nonsense mutations, insertions, deletions etc.) results in the overexpression of PhoPQ system. One of the most important mutations of the $m g r B$ gene, described in Klebsiella spp., is the transposition of extended-spectrum beta-lactamases (ESBLs) or carbapenemase genes. Selective antibiotic pressure and the acquisition of ESBLs and carbapenemase genes could be responsible for the selection of colistin resistance. The role of efflux pump (AcrAB and KpnEF) and hyperproduction of capsule have been described in some polymyxins resistant strains of Klebsiella pneumoniae. Releasing of anionic capsular polysaccharides from the cell surface captures cationic antimicrobial peptides, such as polymyxins, reducing the amount of antibiotics that reaches the site of action (6,10-12).

Mutational alterations of five two-component systems, PmrAB, PhoPQ, ParRS, ColRS and CprRS, have been described in non-fermentative Gram-negative bacteria Pseudomonas aeruginosa. The effect of these mutations is the modification of LPS, efflux pump and outer membrane protein OprH responsible for the stabilization of cell membrane, which could lead to different level of resistance to polymyxins $(6,13)$. Mutations of the $p m r A B$ gene are the main mechanism of resistance to polymyxins in Acinetobacter baumannii. Mutations in $l p x A, l p x C$ or $l p x D$ genes responsible for the lipid A biosynthesis are also very important, because of the complete loss of LPS, but with significant negative impact on fitness and virulence of bacteria $(6,13,14)$.

The occurrence of polymyxins resistance in Enterobacteriaceae was generally related to chromosomally encoded mutations, more often in bacteria exposed to these antibiotics, with vertical transmission of the resistance gene. This paradigm was changed with the discovery of the first plasmid encoded gene responsible for colistin resistance, the $m c r-1$ gene $(11,15)$. Liu YY et al. discovered the mcr-1 gene located on Escherichia coli plasmid in 2015 (16). The product of this gene belongs to the phosphoethanolamine transferase family, which modifies lipid A, similarly to chromosomally encoded modifications. Despite the fact it is not the most common mechanism of resistance, due to its plasmid location and its great possibility for horizontal transfer, it could become the most important one in the future $(10,17)$.

The first discovery of the $m c r-1$ gene was in Escherichia coli isolates of animal origin in China (16). It is located on pHNSHP45 plasmid (IncI2 type), genetic locus named "mcr- 1 cassette", 2600 bp long, with its own promotor (6). Recent studies described other $m c r$-1-carrying plasmids, like IncHI2, IncP, IncFIP, and IncX4 $(18,19)$. Some of them (e.g. IncHI2) are carriers of other antimicrobial resistance genes, like ESBLs, carbapenemases, aminoglycosides, fluoroquinolones and tetracyclines resistance genes $(6,18)$. Jayol et al. showed that the acquisition of the $m c r-1$ gene in Escherichia coli strains with chromosomally-encoded mutations (e.g. pmr $A B$ mutation) leads to a higher level of resistance to colistin (20).

The discovery of the mor-1 gene launched the avalanche of researches, and its presence was detected both in human, animal and environmental bacterial isolates (11) Encouraged by these data, Xavier et al. screened colistin resistant, $m c r-1$ negative animal isolates of Escherichia coli in Belgium, and discovered the $m c r-2$ gene on IncX4 plasmid. A phylogenetic analysis confirmed a significant diversity between MCR-2 and MCR-1 protein. Interestingly, MCR-2 protein shares considerable similarity with lipid phosphatase, the product of insertion sequence IS1595 gene. This phosphatase has a high degree of similarity with phosphatase of Moraxella spp. strains, intrinsically resistant to polymyxins. This homology indicates the 
Brkić S. et al. Polymyxins - Antibacterial Activity, Resistance Mechanisms and Epidemiology of Plasmid Mediated Resistance. MedPodml

possibility of transmission of resistance genes between different species in conditions of cohabitation in animals, humans or in other environments (21). Kieffera et al. confirmed Moraxella spp. as the reservoir of the $m c r$-like gene (22).

Except $m c r-1$ and $m c r-2$, new $m c r$ genes were described in different species. The first $m c r-3$ gene was described in Escherichia coli on IncHI2-type plasmid (23), the $\mathrm{mcr}$ 4 gene in Salmonella spp. and Escherichia coli on ColEtype plasmids (24), mcr-5 also on this type of non-conjugative plasmid, but on Tn3-type transposon (Tn6452) in Salmonella enterica serovar Paratyphi B (25). Very recently, one variant of the $m c r-2$ gene, $m c r-2.2$, was renamed to $m c r-$ $6(26,27)$, and $m c r-7.1$ and $m c r-8$ genes were also described in Klebsiella pneumoniae isolates of livestock origin in China $(28,29)$.

\section{The epidemiology of resistance to polymyxins}

The discovery of plasmid mediated colistin resistance had a huge impact on public health due to its potential of global spreading. Many retrospective studies showed the presence of plasmid mediated colistin resistance in Escherichia coli isolates from chicken in China about 30 years ago, when colistin utilization in veterinary medicine first started (30). The polymyxins usage in animals (e.g. livestock industry), which is 600 times higher than in human medicine, was crucial for spreading this resistance (31). The second joint analysis of the European Centre for Disease Prevention and Control (ECDC), the European Food Safety Authority (EFSA), and the EMA for 2013-2015 period showed that the usage of polymyxins, mostly colistin, in the European Union (EU) countries is higher in food-producing animals than in humans, with significant positive association between the occurrence of colistin resistance and its consumption. Similar positive association was detected only among invasive Klebsiella pneumoniae isolates of human origin in 2015 (32).

An evidence of the animal origin of the $m c r-1$ gene was discovered during the analysis of Escherichia coli urine isolate from an outpatient in Switzerland. Upstream of the mor-1 gene, ISAPI1 insertion sequence was determined, and it was identical to the insertion sequence of Pasteurella multocida, a typical animal pathogen. Additionally, the floR gene was detected in the same isolate, responsible for the resistance to florfenicol, which is used in veterinary medicine only (33).

The latest experimental research has shown that a recombinant plasmid-carrying the $m c r-1$ gene was successfully transferred to Escherichia coli, Klebsiella pneumoniae, and Acinetobacter baumannii, with the introduction of a high level colistin resistance. In Pseudomonas aeruginosa, only moderate changes of susceptibility to colistin were observed (34). This experiment confirms the ability of the horizontal gene transfer between different species.

Up to date, the presence of the $m c r-1$ gene was confirmed in almost all continents, in different species (Escherichia,
Klebsiella, Enterobacter, Cronobacter, Salmonella, Shigella and Kluyvera), isolated from human, animal and food samples (Figure 1) (6,17). During 2014-2015 in the SENTRY Antimicrobial Surveillance Program, colistin-resistant clinical isolates of Escherichia coli and Klebsiella pneumoniae from pacific Asia, Europe, North and South America, showed the incidence of $m c r-1$ gene of 4,9\% in Escherichia coli, but all Klebsiella pneumoniae isolates were $m c r-1$ negative (35). The presence of the $m c r-1$ and the $m c r-2$ was not detected among colistin resistant Klebsiella pneumoniae isolates of human origin in Serbia (36).
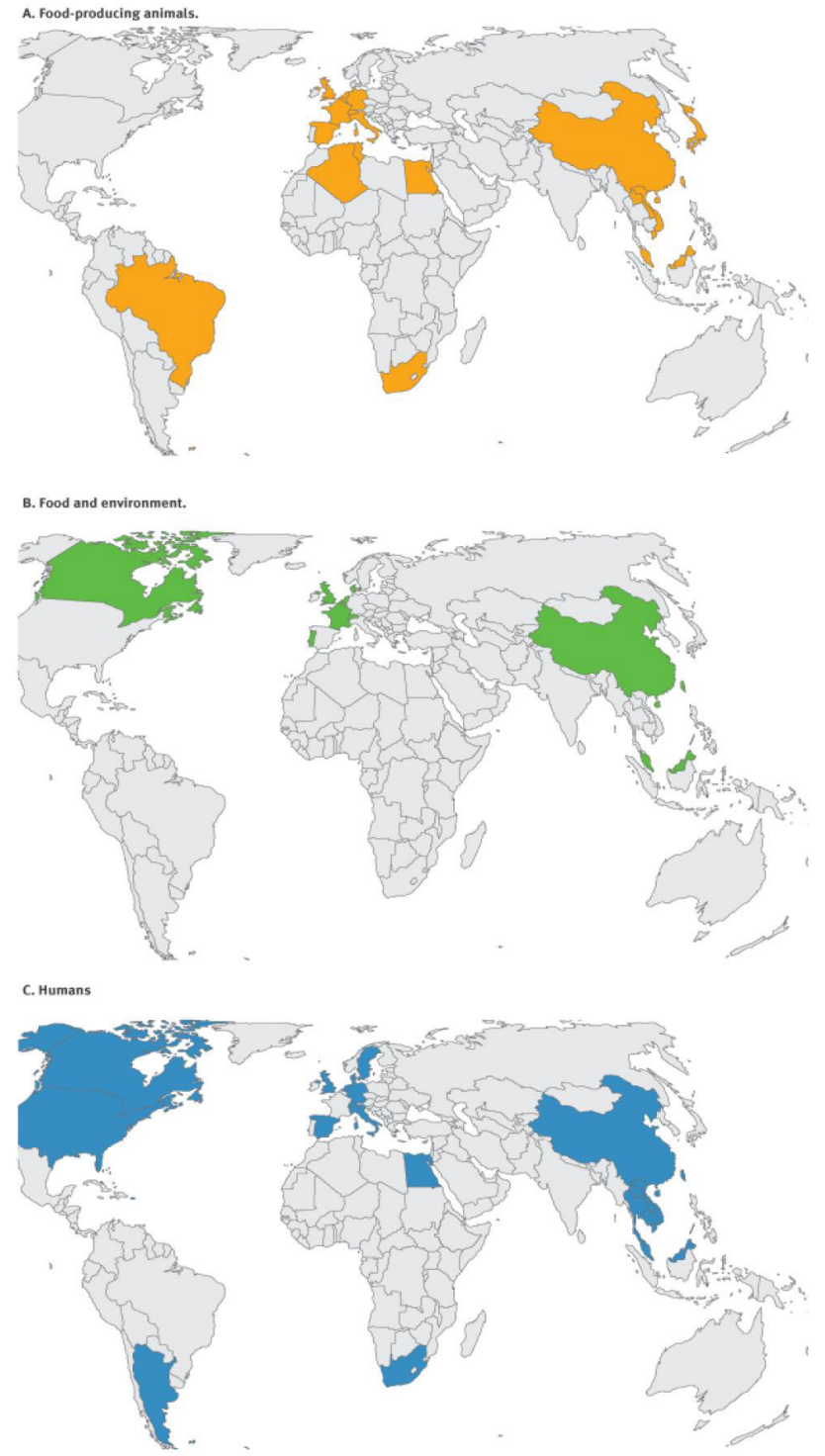

Figure 1. Geographic spread of the $m c r-1$ gene on 2 June 2016 (European Centre for Disease Prevention and Control. Plasmid-mediated colistin resistance in Enterobacteriaceae. Stockholm: ECDC; 2016.)

\section{Conclusions}

The resistance to polymyxins can compromise application of these drugs in human medicine, therefore, the control of polymyxins consumption is necessary in all spheres. In EU countries, the surveillance of the $\mathrm{mcr}-1$ gene is mandatory (17). The World Health Organization in Global Action Plan for Antimicrobial Resistance 
Brkić S. et al. Polymyxins - Antibacterial Activity, Resistance Mechanisms and Epidemiology of Plasmid Mediated Resistance. MedPodml

recommended the control measures for optimal antimicrobial therapy in both humans and animals (37). Detection and surveillance of the resistant isolates on the local, national, and the global level are strongly recommended, due to global epidemiology threat of the plasmid mediated colistin resistance $(6,17)$.

\section{Literature}

1. Magiorakos AP, Srinivasan A, Carey RB, Carmeli Y, Falagas ME, Giske CG, et al. Multidrug-resistant, extensively drug-resistant and pandrug- resistant bacteria: an international expert proposal for interim standard definitions for acquired resistance. Clin Microbiol Infect. 2012 Mar; 18(3):268-81.

2. Lim LM, Ly N, Anderson D, Yang JC, Macander L, Jarkowski A 3rd, et al. Resurgence of colistin: a review of resistance, toxicity, pharmacodynamics, and dosing. Pharmacotherapy. 2010 Dec; 30(12):1279-91.

3. Shahbazi F, Dashti-Khavidaki S. Colistin: efficacy and safety in different populations. Expert Rev Clin Pharmacol. 2015, 8(4):423-48.

4. Kssamali Z, Danziger L. To B or not to B, that is the question: is it time to replace colistin with polymyxin B? Pharmacotherapy. 2015 Jan; 35(1):17-21.

5. Falagas ME, Kasiakou SK. Colistin: the revival of polymyxins for the management of multidrug-resistant gram-negative bacterial infections. Clin Infect Dis. 2005 May 1; 40(9):1333-41. Epub 2005 Mar 22. Review. Erratum in: Clin Infect Dis. 2006 Jun 15; 42(12):1819. Dosage error in article text.

6. Poirel L, Jayol A, Nordmann P. Polymyxins: Antibacterial Activity,Susceptibility Testing, and Resistance Mechanisms Encoded by Plasmids or Chromosomes. Clin Microbiol Rev. 2017, 30(2):557-596.

7. European Medicines Agency. 2014. Polymyxin Article-31referralAssessment report. European Medicines Agency, London, United Kingdom. http://www.ema.europa.eu/docs/en_GB/document_library/Referrals_document/Polymyxin_31/WC500179664.pdf [cited 21.09.2018.].

8. Pogue J, Kaye K. Clinical considerations for optimal use of the polymyxins: A focus on agent selection and dosing. Clin Microbiol Infect 2017; 23(4):229-233.

9. Nation RL, Garonzik SM, Li J, Thamlikitkul V, GiamarellosBourboulis EJ, Paterson DL, et al. Updated US and European Dose Recommendations for Intravenous Colistin: How Do They Perform? Clin Infect Dis. 2016 Mar 1; 62(5):552-558.

10. Osei Sekyere J, Govinden U, Bester LA, Essack SY. Colistin and tigecycline resistance in carbapenemase-producing Gram-negative bacteria: emerging resistance mechanisms and detection methods. J Appl Microbiol. 2016 Sep; 121(3):601-17.

11. Caniaux I, van Belkum A, Zambardi G, Poirel L, Gros MF. MCR: modern colistin resistance. Eur J Clin Microbiol Infect Dis. 2017 Mar; 36(3):415-420.

12. Olaitan AO, Morand S, Rolain JM. Mechanisms of polymyxin resistance: acquired and intrinsic resistance in bacteria. Front Microbiol. 2014, 26; 5:643.

13. Jeannot K, Bolard A, Plésiat P. Resistance to polymyxins in Gram-negative organisams. Int J Antimicrob Agents. 2017 May; 49(5):526-535.

14. Beceiro A, Moreno A, Fernández N, Vallejo JA, Aranda J, Adler $\mathrm{B}$, et al. Biological cost of different mechanisms of colistin resistance and their impact on virulence in Acinetobacter baumannii. Antimicrob Agents Chemother. 2014; 58(1):518-26.

15. Liu YY, Chandler CE, Leung LM, McElheny CL, Mettus RT, Shanks RMQ, et al. Structural Modification of Lipopolysaccharide Conferred by mcr-1 in Gram-Negative ESKAPE Pathogens. Antimicrob Agents Chemother. 2017 May 24; 61(6).

16. Liu YY, Wang Y, Walsh TR, Yi LX, Zhang R, Spencer J, et al. Emergence of plasmid-mediated colistin resistance mechanism MCR-1 in animals and human beings in China: a microbiological and molecular biological study. Lancet Infect Dis. 2016 Feb; 16(2):161-8.
17. European Centre for Disease Prevention and Control. Plasmid-mediated colistin resistance in Enterobacteriaceae. Stockholm: ECDC; 2016.

18. Zurfluh K, Klumpp J, Nüesch-Inderbinen M, Stephan R. FullLength Nucleotide Sequences of mcr-1-Harboring Plasmids Isolated from Extended-Spectrum- $\beta$-Lactamase-Producing Escherichia coli Isolates of Different Origins. Antimicrob Agents Chemother. 2016 Aug 22; 60(9):5589-91.

19. Li A, Yang Y, Miao M, Chavda KD, Mediavilla JR, Xie X, et al. Complete Sequences of mcr-1-Harboring Plasmids from Extended-Spectrum- $\beta$-Lactamase- and CarbapenemaseProducing Enterobacteriaceae. Antimicrob Agents Chemother. 2016 Jun 20; 60(7):4351-4.

20. Jayol A, Nordmann P, André C, Dubois V, Poirel L. Increased colistin resistance upon acquisition of the plasmid-mediated mcr-1 gene in Escherichia coli isolates with chromosomally encoded reduced susceptibility to polymyxins. Int J Antimicrob Agents. 2017 Sep; 50(3):503-504.

21. Xavier BB, Lammens C, Ruhal R, Kumar-Singh S, Butaye P, Goossens $\mathrm{H}$, et al. Identification of a novel plasmid-mediated colistin-resistance gene, mcr-2, in Escherichia coli, Belgium, June 2016. Euro Surveill. 2016 Jul 7; 21(27).

22. Kieffer N, Nordmann P, Poirel L. Moraxella Species as Potential Sources of MCR-Like Polymyxin Resistance Determinants. Antimicrob Agents Chemother. 2017 May 24;61(6).

23. Yin W, Li H, Shen Y, Liu Z, Wang S, Shen Z, et al. Novel Plasmid-Mediated Colistin Resistance Gene mcr-3 in Escherichia coli. MBio. 2017 Jun 27; 8(3).

24. Carattoli A, Villa L, Feudi C, Curcio L, Orsini S, Luppi A, et al. Novel plasmid mediated colistin resistance mcr-4 gene in Salmonella and Escherichia coli, Italy 2013, Spain and Belgium, 2015 to 2016. Eurosurveillance. 2017; 22:31.

25. Borowiak M, Fischer J, Hammerl JA, Hendriksen RS, Szabo I, Malorny B. Identification of a novel transposon-associated phosphoethanolamine transferase gene, mcr-5, conferring colistin resistance in d-tartrate fermenting Salmonella enterica subsp. enterica serovar Paratyphi B. J Antimicrob Chemother. 2017; 72:3317-24.

26. AbuOun M, Stubberfield EJ, Duggett NA, Kirchner M, Dormer L, Nunez-Garcia J, et al. mcr-1 and mcr-2 (mcr6.1) variant genes identified in Moraxella species isolated from pigs in Great Britain from 2014 to 2015. J Antimicrob Chemother. 2018 Oct 1; 73(10):2904.

27. AbuOun M, Stubberfield EJ, Duggett NA, Kirchner M, Dormer L, Nunez-Garcia J, et al. mcr-1 and mcr-2 variant genes identified in Moraxella species isolated from pigs in Great Britain from 2014 to 2015. J Antimicrob Chemother. 2017 Oct 1; 72(10):2745-2749.

28. Yang YQ, Li YX, Lei CW, Zhang AY, Wang HN. Novel plasmid-mediated colistin resistance gene mcr-7.1 in Klebsiella pneumoniae. J Antimicrob Chemother. 2018 Apr 17. doi: 10.1093/jac/dky111. [Epub ahead of print]

29. Wang X, Wang Y, Zhou Y, Li J, Yin W, Wang S, et al. Emergence of a novel mobile colistin resistance gene, $\mathrm{mcr}-8$, in NDMproducing Klebsiella pneumoniae. Emerg Microbes Infect. 2018 Jul 4; 7(1):122.

30. Shen Z, Wang Y, Shen Y, Shen J, Wu C. Early emergence of mcr-1 in Escherichia coli from food-producing animals. Lancet Infect Dis. 2016 Mar; 16(3):293.

31. Skov RL, Monnet DL. Plasmid-mediated colistin resistance ( $m c r-1$ gene): three months later, the story unfolds. Euro Surveill. 2016; 21(9):30155.

32. ECDC (European Centre for Disease Prevention and Control), EFSA (European Food Safety Authority), and EMA (European Medicines Agency), 2017. ECDC/EFSA/EMA second joint report on the integrated analysis of the consumption of antimicrobial agents and occurrence of antimicrobial resistance in bacteria from humans and food-producing animals - Joint Interagency Antimicrobial Consumption and Resistance Analysis (JIACRA) Report. EFSA Journal 2017; 15(7):4872 
Brkić S. et al. Polymyxins - Antibacterial Activity, Resistance Mechanisms and Epidemiology of Plasmid Mediated Resistance. MedPodml 2019, 70(3):1-6

33. Poirel L, Nordmann P. Emerging plasmid-encoded colistin resistance: the animal world as the culprit? J Antimicrob Chemother. 2016 Aug; 71(8):2326-7.

34. Liu YY, Chandler CE, Leung LM, McElheny CL, Mettus RT, Shanks RMQ, et al. Structural Modification of Lipopolysaccharide Conferred by mcr-1 in Gram-Negative ESKAPE Pathogens. Antimicrob Agents Chemother. 2017 May 24; 61(6).

35. Castanheira M, Griffin MA, Deshpande LM, Mendes RE, Jones RN, Flamm RK. Detection of $m c r-1$ among Escherichia coli Clinical Isolates Collected Worldwide as Part of the SENTRY Antimicrobial Surveillance Program in 2014 and 2015. Antimicrob Agents Chemother. 2016, 60(9):5623-4.
36. Novović K, Trudić A, Brkić S, Vasiljević Z, Kojić M, Medić $\mathrm{D}$, et al. Molecular Epidemiology of Colistin-Resistant, Carbapenemase-Producing Klebsiella pneumoniae in Serbia from 2013 to 2016. Antimicrob Agents Chemother. 2017 Apr $24 ; 61(5)$

37. Global action plan on antimicrobial resistance. Geneva: World Health Organization; 2015. http://apps.who.int/iris/bitstream/10665/193736/1/9789241509763_eng.pdf?ua=1 [cited 26.09.2018.] 